\title{
PEDAGOGY OF FINANCIAL EDUCATION AMONG COLLEGE STUDENTS
}

\author{
Michael Ben Jacob
}

Neri Bloomfield School of Design and Education, Israel, phasis@netvision.net.il

\begin{abstract}
The level of economic thinking and financial culture of population should be considered one of the most important components of society's economic life quality. Here, a key factor is economic and financial socialization of an individual, which can be achieved mainly by modelling appropriate training process technology to promote and ensure financial awareness at the early stages of training in high school and later on in colleges and universities. This paper focuses on one of the options of a unique subject matter (course) in Financial Education, for which testing started in 2008 and is successfully continuing in the Department of Business Management of Neri Bloomfield School of Design and Education (Haifa, Israel) against the backdrop of a multicultural environment. The study shows the dynamics of the formation of the main teaching methods of the new course. In parallel, we analysed the results of the final examinations of students to further adjust the content and pedagogy of the educational process. The results once again confirmed the urgent need to improve the financial literacy of students in accordance with the challenges of economics and culture in the twenty-first century.
\end{abstract}

Keywords: Pedagogy of financial education; college students; multicultural environment in Israel

Type of the paper: Empirical study

JEL Classification: A2

\section{Introduction and Literature Review}

The need to revitalize young individuals' activities in the financial sector should be recognized as one of the major challenges of the modern society in the field of higher education. In this regard, various aspects of a phenomenon known as financial education are widely studied in the scientific literature. This paper discusses some of them.

A. This problem is the focus of international organizations such as the World Bank, Organization for Economic Cooperation and Development (The Case for Financial Literacy in Developing Countries 2009), (Xu, Zia 2012), and the European Commission (Habschick et al. 2007), which concentrate their attention on the interdependence of financial education and sustainable economic development. In almost all countries, special government programs are developed and implemented to promote financial literacy, for example, in Australia (Australian Securities and Investment Commission 2011); in Canada, (Orton 2007), etc. In Israel, in the year 2012, under the Ministry of Finance, in a special unit of financial education, a document was developed to discuss the national strategy to promote financial education in Israel (National Strategy to Promote Financial Education in Israel 2012).

B. The epistemological foundations of financial education are studied, including:

- the essence and content of financial education in the context of financial capability (Reifner, Schelhowe 2010; Sherraden 2010) among youth (Johnson, Sherraden 2007);

- the relationship between financial literacy and financial socialization (Gudmunson, Panes 2011; Solheim et al. 2011), as well as financial education and economic development in the context of the study of such phenomenon as "financially educated" person (Hogarth 2006);

- ways of optimal transformation of knowledge into practical activities in the financial sector (Kiviat, Morduch 2012). 
C. A whole series of publications examine the issue of financial literacy among young people (Sami et al. 2008; Lusardi et al. 2010), considering college students as a separate group (Chen, Volpe 1998; Volpe et al. 2002; Chen, Volpe 2002; Mandell, Klein 2009; and Stoll, Pumpe 2009). In these publications, the authors have specifically analyzed the data on financial literacy among Israeli college students (Sharabani 2013).

Summarizing the results of the literature review, we can see that, despite the abundance of scientific and methodical literature on this problem, from our point of view, there is a clear lack of research on such an important component as the Pedagogy of Financial Education, and, in particular, with regard to higher education. Concerning the known scientific publications, the exceptions are:

1. The trainers' manual of International Labour Organization (Financial Education for Youth 2011) clearly substantiates a detailed structure of the curriculum related to young people aged 15-29, that is, the life stage when a transition from financial 'dependence' to financial 'independence' occurs.

2. One of the publications provides a comparative analysis of the curricula on the basis of 100 educational institutions - members of the Association to Advance Collegiate Schools of Business (AACSB) (Bianko, Bosco 2011).

It is due to the lack of research in this direction that the author chose Pedagogy of Financial Education as the object of analysis. But before we proceed towards a direct presentation of the nature of the object under study, I would like to note the following: Today, we can say that almost all higher education institutions, regardless of their specialization, make serious efforts to promote financial education, mainly by highlighting certain issues and topics in various courses.

But this situation cannot be considered satisfactory. In our view, this is due to the fact that all hitherto existing financial education is basically 'superficial'. There is an urgent need to make the process of promoting Financial Education that is holistic in nature, and this can be achieved only through the implementation of a special course in the learning process. We favour an approach whereby such a course would be comprehensive and include all kinds of components, the mastery of which will subsequently contribute to the development of optimal behaviour in individuals in the financial sector of public life.

We evaluated this approach in the Business Management Department of our educational institution, acting under the auspices of Consul for Higher Education of Israel. Our choice was not accidental, as the specified department awards Bachelor's Degree in Education (BEd) within their Business Management Program. Additionally, our college specializes in training teachers for teaching economy and management subjects in high school. Recently, a course 'Financial Education' was added to the list of courses for teaching, and has been started as a pilot course in some Israeli schools.

In this department, there are special academic groups, where the majority of students are ethnic and religious minorities (Arab Muslims, Arab Christians, Druze), and a minor part is Jewish. In these groups with multicultural background, on our initiative and with the approval of management, a pilot project on introducing the course "Financial Education" into educational process was launched for the first time in 2008. The course title was dictated by the specifics of our college, which issues Teaching Certificates along with awarding academic degrees. In some cases, other variants of the course title are possible: 'Household Financial Management', 'Financial Behaviour', 'Personal Finance', etc. A very similar project has been launched in the United States in Kent State University by implementing a personal financial literacy elective course 'Me and my Money' within the undergraduate program (Stolle, Dumpe 2009).

In this article, we would like to share with readers the experience gained in this area. The specified course outgrew the scope of educational experiment and today has become an integral part of the educational process. 


\section{Methodology}

First, we used the scientific methods of observation, generalization and abstraction, which allowed us to design a model of educational experiment, as well as to visualize the learning process in the initial stage of developing a study course.

Second, the process of introducing a new course in the educational process was under constant monitoring, which involved active dialogue with the students and also a quantitative measurement of the results achieved. To this end, we chose the method of measurement of the results of the final examinations, where students, as a rule, tend to concentrate more, and their answers reflect the greatest confidence. Thus, the examination data for 301 students were processed. This approach allowed us to actively adjust the content and teaching methods of the educational process in each subsequent study group.

The next important element of the educational process is the final control of knowledge acquired by students. In most cases, we developed multiple choice questions for the examination. Further ahead in this paper, we offer our readers an opportunity to acquaint themselves with some of the typical questions from our bank of questions of our Financial Education course.

\section{Results}

\section{Principles and Content of Financial Education among College Students}

Our vision of the mission of Financial Education in colleges can be summarized as the need to prepare students to successfully embed themselves in the financial sphere of public life. Hence, the starting point of construction of the Financial Education system should be to identify those social roles that young people have to play, for objective reasons, in the economic and financial sphere of public life. The following 'roles' should be recognized as social: 1) a household owner and taxpayer, 2) a manpower in the labour market, 3) a reasonable consumer, and 4) an entrepreneur.

The structure of the course was elaborated on the basis of refined social roles performed by young people. As already mentioned, we support the approach which assumes that any course promoting Financial Education is inherently complex and must include economic, financial, social and legal components of life that are, to some extent, related to the nature of financial behaviour of the individual. It is clear that such an approach can be a 'trap', since it is very difficult to 'construct' a course covering all aspects of this particular field and, at the same time, not to turn it into a universal course, such as a simple set of knowledge of banking, finance, entrepreneurship, etc. It is known that modern higher schools suffer much from a lack of training hours. Therefore, it is very important to identify and include the most pressing issues in the course.

\section{Visualization of Learning Process in the Course 'Financial Education'}

Achieving positive and desired results from teaching the course of Financial Education is largely predetermined by the use of appropriate tools in order to optimize the perception of educational material by the students, the vast majority of whom, as known from educational psychology, sometimes prefer a visual type of perception in the learning process. At the same time, in the scientific literature, a wide range of tools are recommended. The most recognized mapping tools are mind map, concept map and argument map (Biktimirov, Nilson 2006; Bouzdine-Chameeva 2009; Davies 2011). Different versions of Ishikawa cause-and-effect diagrams (Ishikawa 1985) are also widely used. The decision on which tool to use is not so significant, but the process of transmission of educational material by visual means is important. Towards the end of this paragraph, we have illustrated the various uses of visual aids in teaching the course of Financial Education. At the beginning of the course, we demonstrate to the students the conceptual logical model of this subject, developed on the basis of system analysis (Fig. 1). 


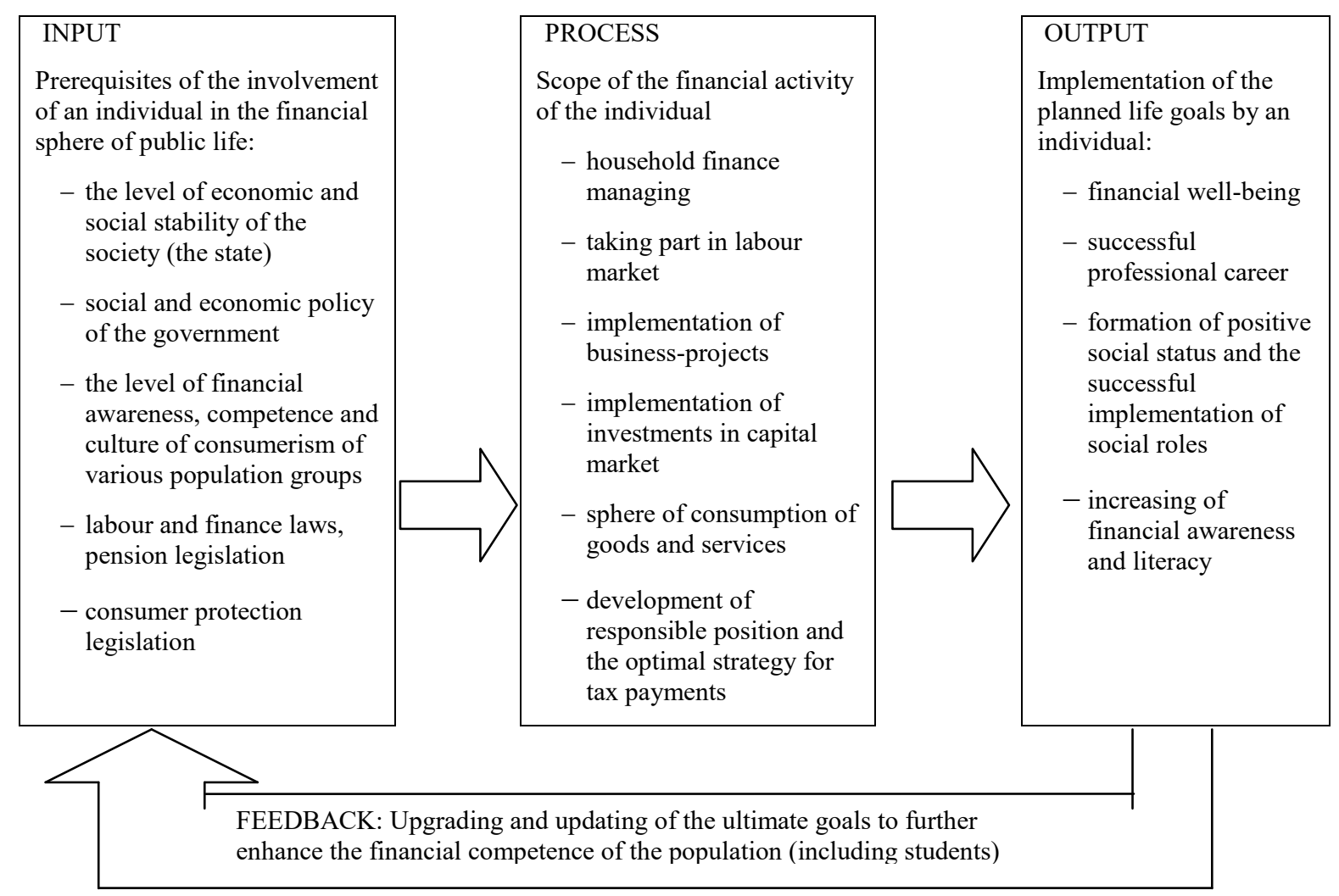

Fig. 1. Conceptual Model of Studying the Course Financial Education

Additionally, we demonstrated to the students the options of logical models on selected topics to illustrate the training material. Possible elements of personal finance planning are presented in Fig. 2.

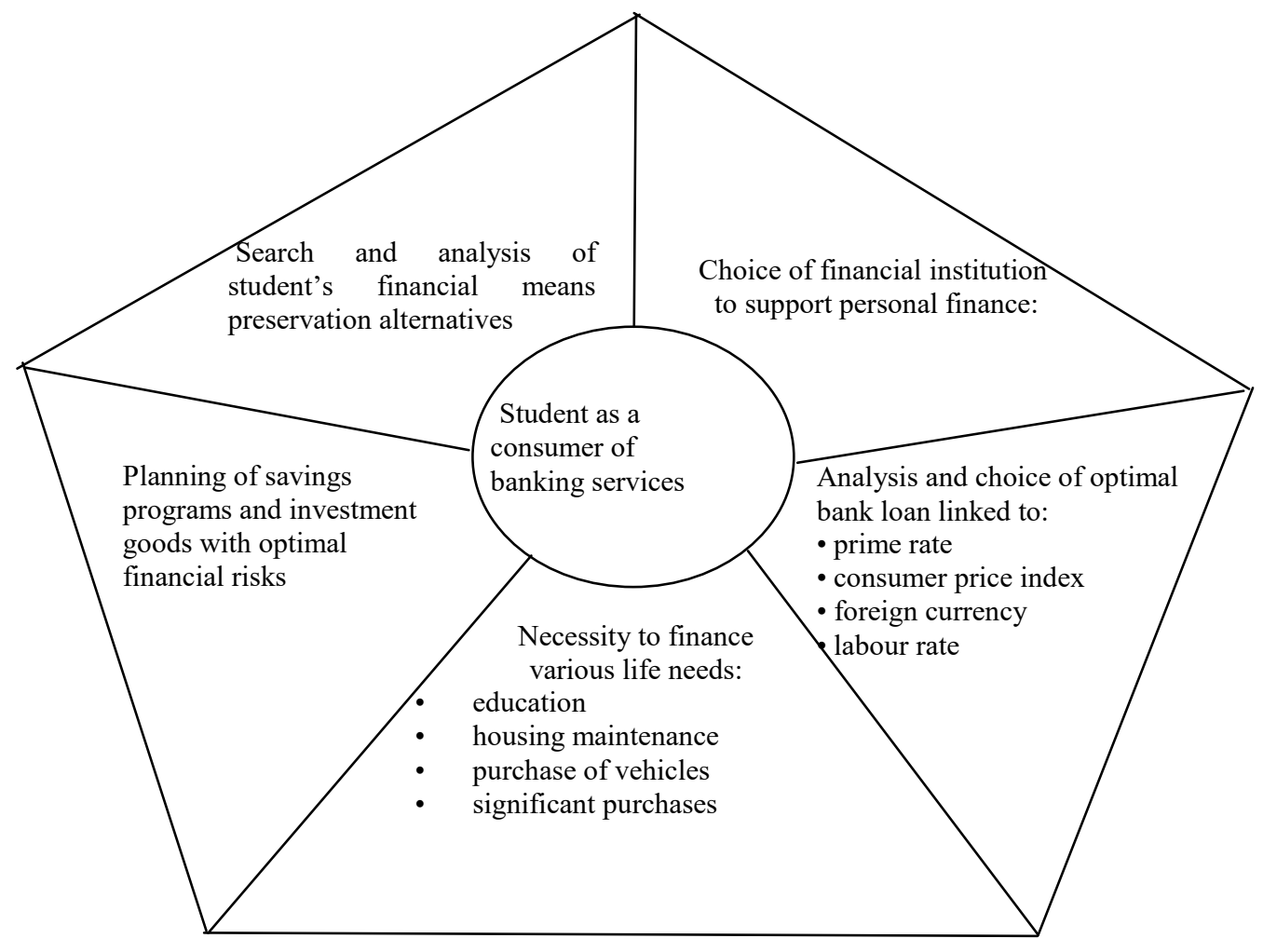

Fig. 2. Possible elements of planning personal finance 
Elements forming optimal pension strategy are presented in Fig. 3.

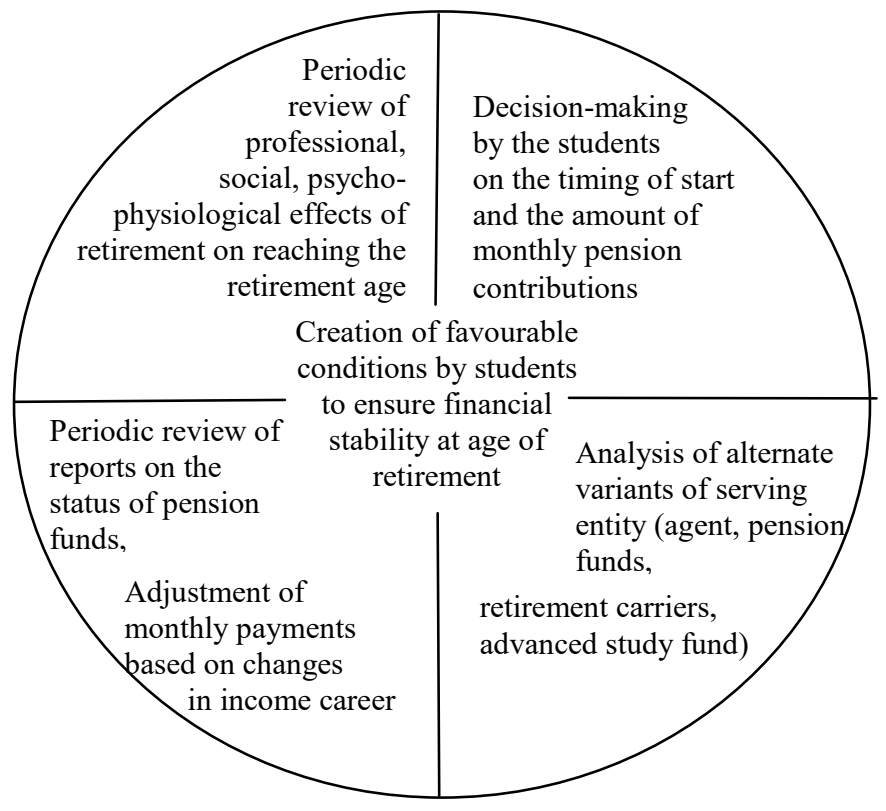

Fig. 3. Elements of an optimal pension strategy developed by the student

Components required to introduce an individual to entrepreneurship are presented in Fig. 4.

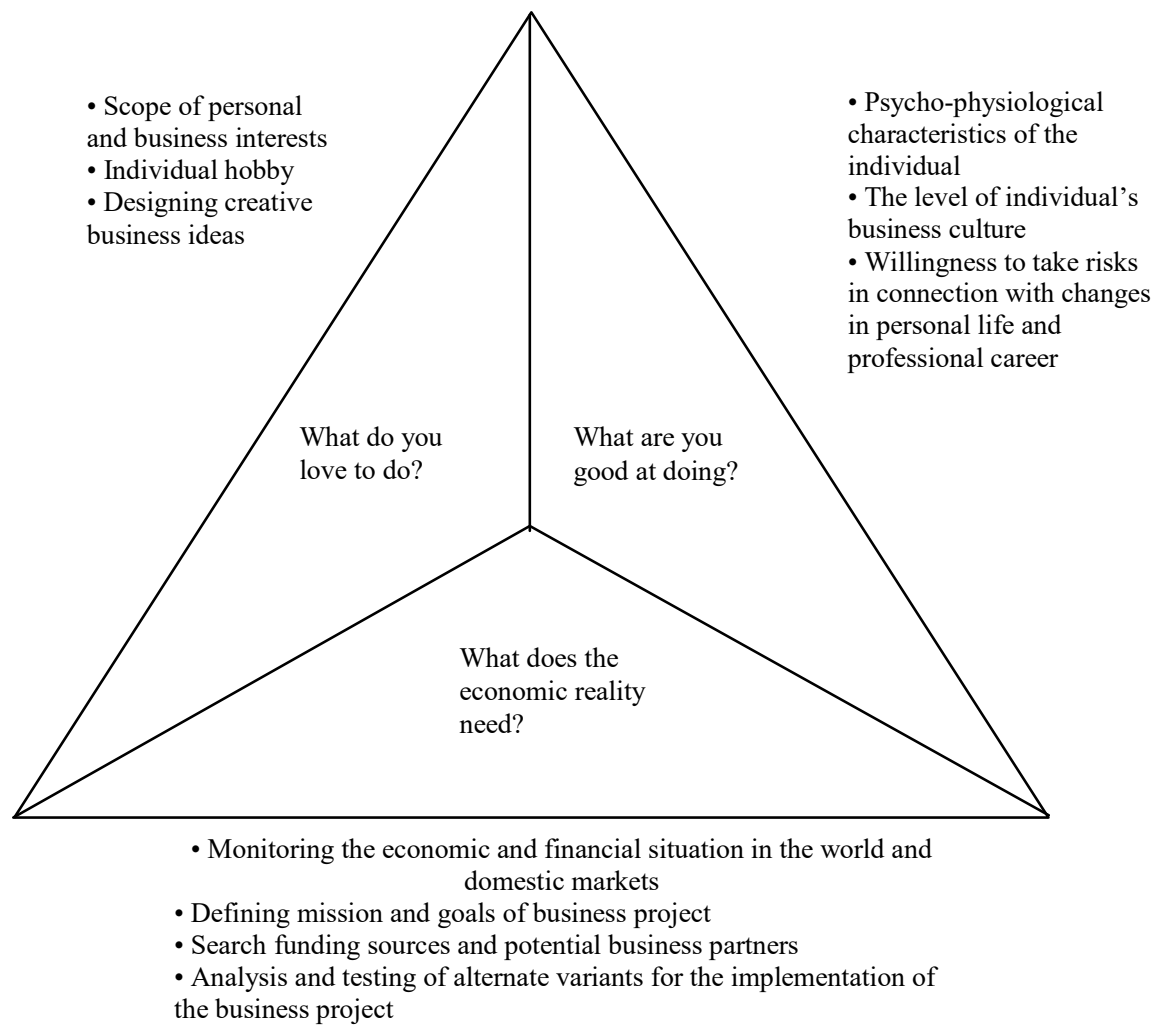

Fig. 4 . The necessary components for familiarizing the individual with entrepreneurship 
Only visualization of the educational material, for all its importance, does not necessarily solve all the problems of teaching. To achieve the desired results, it is necessary to select appropriate instructional teaching resources.

\section{Instructional Methods in the Teaching of the Course}

Due to the fact that neither in Israel nor in other countries there is a universally accepted textbook for the course of Financial Education, as is available for similar courses of Micro and Macroeconomics, Financing, Audit, Accounting, Organizational Behavior, Management and such, we have to provide each student with the appropriate theoretical and practical material on all topics, including case studies to be analyzed at lectures as well as theoretical and visual materials. All the materials are distributed to the students. At the same time, in the learning process, special attention is given to the selection of specific teaching techniques. First, we present several major points that need special attention and adjustment in order to achieve a successful economic adaptation.

\section{Designing the Culture of Household Management in the New Economic Environment}

We recommend to each youngster to learn how to plan their family incomes and expenses. Of late, computer software for managing and controlling the family expenses, and home accounting have becomes available in the market. These softwares enable the creation of records detailing the list of incomes and expenses. It supports tables, including subjective tables, family members and bank accounts. There is a chart that shows operations by percentages. This form of accounting is very realistic for young people, especially when there is a lack of tradition regarding management of family budget.

\section{The Student (Youngster) and the Country's Banking System}

One needs to explain to youngsters the importance of the country's banking system. We are ready to give 'tips' that relate to cash flow, how to use cheques, credit cards, etc. Furthermore, youngsters need to learn saving plan conditions and possibilities of getting loans for studies and additional needs. Youngsters must also acquire knowledge in the following fields:

- What is the meaning of choosing 'the right bank' or 'the wrong one' for youngsters?

- How to create an optimal saving plan?

- What are nominal, effective and realistic interests?

- What is the meaning of the Bank of Israel interest and prime interest?

- How to use the right for 'overdraft' and to act rationally with this right?

- How to save bank commissions?

- How to register for a loan to finance studies?

\section{Acquiring Habits for Renting a House or for Purchasing the First Home.}

\section{Planning for the Purchasing Process}

We find that the search for a house is at the top of the student's pyramid of priorities, especially if we talk about a young couple, and it is a very complex issue.

A. How does a potential residence fit with the location of the college and of occupation at present?

B. In which area do they prefer to live? 
Only after a youngster answers these questions can he make a decision regarding purchasing a house. Nonetheless, if we talk about purchasing a house, he must plan it from an economic point of view and make the following decisions:

- In which bank is it preferable to organize the mortgage and bank loan?

- How to create an economic plan for purchasing a house?

- Which type of loans to choose from for purchasing a house?

\section{Development of Wise Consumer Habits Amongst Youngsters}

Today, among youngsters, there is a prominent feeling of buying things 'with no money' meaning that people buy products by using credit cards or via the Internet. In this situation, it is very difficult to buy rationally.

\section{'I buy this product because it is excellent.'}

This stands out in the youngsters' thoughts. They need to buy according to the principle:

\section{'We buy a product that is necessary for the household at this time.'}

In addition, we present a few more 'tips' for the youngsters' economic 'survival'.

\# Don't think that you will be young forever. Care for the 'Golden Age' (retirement) from your young age.

\# Don't exaggerate while evaluating your economic situation, examine it realistically. It means that it is more preferable that people around think you are 'a miser' comparing with the situation when you get warning letters from the bank every month. It is better to live in a regular home without overdraft than in a villa with an overdraft and limited account.

\# Determine for yourself and keep a few warning points regarding your financial condition, which you can't break.

\# Teach yourself how to design clear financial goals in life (studies, creating a family, purchasing a home, car, travelling abroad, etc.) according to your economic situation.

\# Keep a strict discipline regarding documents that relate to the family economy, and don't throw away any document before the expiry date that is marked on it. You need to remember that a document isn't only piece of paper, but it is a proof with legal meaning regarding different subjects.

The next important element of the educational process is the final control of students' knowledge carried out during the final examination. In most cases, we are developing examination questions on the principle of multiple choices. Some of the typical examination questions of our Financial Education course from our bank of questions are presented in the Appendix.

\section{Conclusions}

In order to achieve substantial progress in further promoting financial awareness, there is an urgent need to improve the level of financial literacy and competence of the society. As a result, the financial security of the population will increase significantly, especially when it comes to college students. To do this, you must make the process of financial education systemic in nature, and not a one-time measure. Such a process should be organically woven into the system of continuous economic (financial) education, and include various forms of formal and informal education through the media and popular literature for a wide range of readers, and also directly through the formation of a coherent system of financial education in secondary schools and higher education institutions (universities and colleges).

Despite the fact that, in recent years, higher education institutions have turned their attention to the promotion of financial education, the results of surveys indicate a lack of effective steps. The main 
reason, in our view, lies in a non-systematic approach to this issue. For example, college students study a variety of issues in a scattered and fragmented form within various training courses. Apparently, the maximum effect can be achieved only through the implementation of specialized courses of Financial Education into the study process.

Here, it is important to avoid a situation where the new course will be a mechanical repetition and return to the concepts that the student has studied in various academic disciplines of economic and financial orientation. It is necessary, in the process of teaching this course, to focus not so much on mastering conceptual apparatus in the field of financial knowledge (which in itself is also important) by the students, but on the formation of modern financial thinking and contributing to effective use of financial instruments in everyday reality for the successful settling and solving of financial operations during their contact with various organizations and individuals.

\section{Acknowledgements}

Support for this work was provided by the MOFET (Research, Curriculum and Program Development for Teachers and Educators) Institute in Israel and Neri Bloomfield School of Design and Education, Haifa, Israel.

\section{References}

Australian Securities and Investment Commission "National Financial Literacy Strategy", (2011). [Accessed 25.08.2015]. Available from Internet: http://www.financialliteracy.gov.au/media/218312/national-financialliteracy-strategy.pdf

Bianko, C., \& Bosco, S.M.Financal Literacy: What are Business Schools Teaching? Journal of Global Business Management, 7(1), (2011):1-8.

Biktimirov, E.N., \& Nilson, L.B. (Fall 2006). Show Them the Money: Using Mind Mapping in the Introductory Finance Course. Journal of Financial Education, (32), 72-86.

Bouzdine-Chameeva, T. (2009). Locating in Conceptual Space: Using Mapping Tools in Teaching, Presentation Summary. Bordeaux Management School, 1-3.

Chen, H., \& Volpe, R.P. (1998). Analysis of Personal Financial Literacy among College Students. Financial Services Review, (7(2)), 107-128. [Accessed 25.08.2015]. Available from Internet: http://ceur-ws.org/Vol458/panel1.pdf

Chen, H., \& Volpe, R.P. (2002). Gender Differences in Personal Financial Literacy Among College Students. Financial Services Review, (11(3)), 289-307.

Davies, M. (2011). Concept Mapping, Mind Mapping and Argument Mapping: What are the Differences and Do They Matter? Higher Education, (62(3)), 279-301.

Financial Education for Youth. Trainer's Manual (2011). Kathmandu: ILO Country Office for Nepal.

Gudmunson, C.G., \& Panes, S.M. (2011). Family Financial Socialization: Theory and Critical Review. Journal of Family and Economic Issues, 32(4), 644-667.

Habschick, M., Seidl B., \& Evers, J. (2007). Survey of Financial Literacy Schemes in the EU27. Hamburg, Germany.

Hogarth, J.M. (2006). Financial Education and Economic Development. [Accessed 25.08.2015]. Available from Internet: $\underline{\text { http://www.oecd.org/dataoecd/20/50/37742200.pdf }}$

Ishikawa, K. (1985). What is Total Quality Control? The Japanese Way. London, England: Prentice Hall.

Johnson, E., \& Sherraden, M.S. (2007). From Financial Literacy to Financial Capability Among Youth. Journal of Sociology and Social Welfare, (34(3)), 119-145.

Kivial, B., \& Morduch, J. (2012). From Financial Literacy to Financial Action. A White Paper for the McGrawHill Research Foundation, (January 2012), 1-20.

Lusardi, A., Mitchell, O.S., \& Curto, V. (2010). Financial Literacy Among the Young. The Journal of Consumer Affairs, (44(2)), 358-380. 
Mandell, L., \& Klein, L.S. (2009). The Impact of Financial Literacy Education on Subsequent Financial Behaviour. Journal of Financial Counselling and Planning Education, (20(1)), 15-24.

Orton, L. (2007). Financial Literacy: Lessons from International Experience. Ottawa, ON: Canadian Policy Research Networks.

Reifner, U., \& Schelhowe, A. (2010). Financial Education. Journal of Social Science Education, (9(2)), 32-42.

Samy, M., Tawfic, H., Huang, R. \& Nagar, A..K.' Financial Literacy of Youth. A Sensitivity Analysis of the Determinants,' International Journal of Economic Sciences and Applied Research 1(1),(2008):55-70

Sharabani, S. (2013). Financial Literacy Among Israeli College Students. Journal of College Student Development, (54(4)), 439-446.

Sherraden, M. S. (2013). Building blocks of financial capability. In J. M. Birkenmaier, M. S. Sherraden, \& J. C. Curley, J. (Eds.) Financial Capability and Asset Building: Research, Education, Policy, and Practice, 1-43. New York \& Oxford: Oxford University Press.

Solheim, C.A., Zuiker, V.S., and Levchenko, P. (2011). Financial Socialization Family Pathways: Reflections from College Students' Narratives. Family Science Review, (16(2)), 97-112.

Stolle, R., \& Dumpe, D. (2009). Developing the Personal Financial Literacy of College Students. Kent, Ohio: Kent State University. [Accessed 25.08.2015]. Available from Internet: www.abeweb.org/proceedings/proceedings09/stolle.pdf

The Case for Financial Literacy in Developing Countries, Promoting Access to Finance by Empowering Consumers. (The World Bank, 2009). [Accessed 25.08.2015]. Available from Internet: www.globalbrigades.org/media/Financial_Literacy.pdf

Volpe R.P., H. Chen, \& Pavlicko, J.J. (1996). Personal Investment Literacy Among College Students: A Survey. Financial Practice \& Education: Fall/Winter,Vol.6. Issue 2, 86-94.

$\mathrm{Xu}$ Lisa, Bilal Zia. Financial Literacy Around the World: An Overview of the Evidence With Practical Suggestions for the Way Forward. The World Bank, Development Research Group Finance and Private Sector Development Team: June 2012. WPS6107. 


\section{Appendix}

\section{Typical exam questions (Multiple Choice) in subject matter "Financial Education"}

1. According to the norms that are customary in the world, a family, that takes mortgage, can afford itself to plan repayment extent of the monthly average payment of $(82 \%)$ :
A. $\quad * 25 \%$ of monthly family income.
B. $\quad 10 \%$ of monthly family income.
C. $\quad 35 \%$ of monthly family income.
D. $20 \%$ of monthly family income.

2. What are preferable ways to cancel the overdraft of a customer's bank account? (6\%)

A. To arrange a loan with the help of a bank clerk.

B. To close current bank account.

C. $\quad *$ To reduce the expenses extent of the family budget.

D. Answers $\mathrm{A}$ and $\mathrm{C}$ are the correct answers.

3. Any type of credit card is not designed for $(82 \%)$ :

A. For expensive purchasing deal.

B. * For reducing expenses of family economy.

C. Using instead of cash.

D. For withdrawing cash.

4. In Israel, payment for the bank account overdraft is carried out (63\%):

A. On 15 of month.

B. On 28 of month.

C. * On the quarter last day.

D. Answers A and B are the correct answers.

5. Banks in Israel determine loan interest rate based on (94\%):

A. $\quad$ * PRIME interest.

B. Management opinion.

C. Israeli government decision.

D. Answers A and $\mathrm{C}$ are the correct answers.

6. During the mortgage loan arrangement, a customer must clarify the following parameters $(75 \%)$ :

A. Interest rate for loan (mortgage).

B. Monthly repayment sum.

C. Israeli government decision.

D. * All parameters.

7. One can keep the value of money in the following ways (38\%):

A. Keeping the money in a safe at home or under the tiles.

B. Keeping the money in bank current account.

C. $\quad$ * Depositing money in savings plans and Short Term Deposit.

D. Answers B and $\mathrm{C}$ are the correct answers.

8. While choosing a bank it is preferable that the consumer will pay attention to (57\%):

A. * What kind of status the bank is willing to give the customer.

B. Branch location.

C. Branch accessibility.

D. Amount and type of commissions which are determined in the bank.

9. What factors should be considered while making a decision about investing in stocks? $(88 \%)$

A. Investment profitability.

B. Extent of endangering the investment.

C. Investment liquidity.

D. * All the answers are correct. 
10. A student works as a waiter in a restaurant. At the end of month the restaurant owner calculates the salary and includes into the salary the tips that the waiter received. What is the most accurate statement? $(70 \%)$

A. $\quad *$ Wrong, because tips are not considered as part of the waiter's salary.

B. Right, because the waiter received tips by using the assets (tableware, equipment, furniture) of the restaurant owner.

C. Right. As tip is calculated as the restaurant income and is registered in the cash register, it is considered as part of the salary.

D. Answers B and C are the correct answers.

11. A wage which is paid to a worker is considered as $(100 \%)$ :

A. A support of governmental institutes for the citizen.

B. A support for the worker in order to pay current payments of the family economy.

C. * A payment for work that the worker has done during the month for the employer.

D. All answers are correct.

12. Which of the following statements for convalescence pay is right? $(50 \%)$

A. For a person who wants to go on vacation to the Dead Sea, Eilat or Turkey.

B. For covering expenses in order to keep the worker's health.

C. Every worker who is employed in the organization more than a year deserves it.

D. * Answers B and $\mathrm{C}$ are the correct answers.

13. A factory worker stays overtime upon the request of a manager. In this case $(88 \%)$ :

A. $\quad *$ He is paid a payment for overtime in his monthly salary

B. He is paid a bonus.

C. He is paid $13^{\text {th }}$ salary (additional salary).

D. He is not paid, on the contrary, as a punishment it will be reduced from his daily wage.

14. Compensations are paid when dismissing a worker as a result of $(88 \%)$ :

A. A request of the worker himself.

B. An initiative of the employer himself.

C. * Benefits which are paid in connection with the dismissal from work according to labour laws in Israel.

D. This is a payment that is paid selectively to different sectors.

15. Every Israeli citizen pays either way (38\%):

A. Income tax.

B. Purchase tax while purchasing electric appliances.

C. * National insurance premiums.

D. Answers B and C are the correct answers.

16. Which statement of the following ones regarding pension is right? (44\%)

A. Kind of saving money.

B. Sum that is paid to a worker by an employer according to his will and economic laws.

C. Type of a mandatory savings that each individual must organize.

D. * All answers are correct.

17. A life insurance premium of the Israeli citizen is paid by $(100 \%)$ :

A. $\quad *$ The citizen.

B. By the state.

C. By national insurance institute of Israel.

D. All answers are correct.

18. Decision making as regards to business opening is most worthwhile and right for (94\%):

A. Someone who is unemployed and a pensioner.

B. Someone who is willing and preparing to get support from his family members.

C. Someone who has liquid money on his bank account.

D. * Someone who has a special business idea.

19. Which of the following documents is used in business? $(100 \%)$

A. Invoice.

B. Receipt 
C. Order and delivery note.

D. * All answers are correct.

20. According to Israeli national insurance laws, a salaried employee is considered as work accident injured person in case of $(82 \%)$ :

$\begin{array}{ll}\text { A. } & \text { Being injured while playing football with friends. } \\ \text { B. } & \text { Work accident. } \\ \text { C. } & \text { Professional illness. } \\ \text { D. } & \text { Answers B and C are correct. }\end{array}$

21. In Israeli economic life, every citizen in a certain age plays the following roles (75\%):

A. Labour force and entrepreneur.

B. Child, parent and close relative.

C. Consumer and individual in household.

D. * Answers B and C are correct.

22. Individual is considered as a wise consumer if at the time of buying products or services he acts according to the principle to buy (94\%):

A. Each one of the good products.

B. Only basing on the family members, friends and work colleagues advices.

C. Only when there are actions and cheaply.

D. * Only that the family needs.

23. In order to save electricity, it is preferable (38\%):

A. To purchase electric appliances with $\mathrm{G}$ sign (of product energy consumption).

B. Based on the electricity company, to adjust central air-conditioning to $26^{\circ}$.

C. To often clean sun-heated water tank glasses.

D. * Answers B and $\mathrm{C}$ are correct.

24. What action presents the higher degree of satisfaction of the customer? $(82 \%)$

A. He thanks for the discount.

B. He smiles at the end of purchasing.

C. He leaves a tip for the seller.

D. * He comes back for a second purchasing at the same store.

25. A consumer bought salads in supermarket and noticed that the weight includes the packing also. Is it legal? (19\%)

A. Of course.

B. * The supermarket has to subtract the weight of package from the total weight and charge only for salad itself.

C. If there is a sign - it is permitted.

D. It depends on what you bought. If humus, it is permitted, if eggplants - it is not allowed.

26. A consumer bought a train game for children, with a picture of a huge train. Inside the package was a tiny train. The salesperson says the near the picture there is a note "for demonstration only". (63\%)
A. * It might be considered as a deception.
B. So what? On commercials all are models and in the real life they are not.
C. Only in children games a different law is applied, and therefore it is not a crime.
D. The law is different regarding the Israeli products that are designed for export.

27. What is "shrinking packaging"? (44\%)

A. A Phenomenon when product packages shrink as a result of heat around it on the shelf.

B. A phenomenon when product packages shrink in relation to their advertisement.

C. $\quad *$ A phenomenon when producers leave a big product package, but reduce its content.

D. Answers A and B are the correct answers.

The letter with $(*)$ means the right answer.

$(\mathrm{x} \%)$ means that $\mathrm{x} \%$ of students answered correctly. 